ISSN 1411 - 0067 Jurnal Ilmu-Ilmu Pertanian Indonesia. Volume 9, No. 2, 2007, Hlm. 77 - 84

\title{
KETERKAITAN SEKTOR DAN SEKTOR UTAMA DALAM PEREKONOMIAN PROPINSI BENGKULU: ANALISA INPUT- OUTPUT
}

\author{
SECTORAL LINGKAGE AND KEY SECTOR IN PROVINCE BENGKULU \\ ECONOMY: INPUT-OUTPUT ANALYSIS
}

\author{
Ketut Sukiyono, M Mustopa Romdhon, dan Musriyadi Nabiu \\ Jurusan Sosial Ekonomi Pertanian Fakultas Pertanian Universitas Bengkulu \\ Jln Raya Kandang Limun Bengkulu 38371A \\ ksukiyono@yahoo.com
}

\begin{abstract}
The objective of research was to evaluate backward (BL) and forward linkages (FL) and to determine key sectors which have large contribution to Bengkulu economy. The linkages and key sector analyses were applied to the Bengkulu Input-Output Tables 2000. The results showed that the structure of the Bengkulu economy still remain dominated by agricultural sectors. Three agricultural sectors, i.e, palm oil, other agriculture, husbandary and their products, were the key sectors in Bengkulu economy indicated by strongest BL and FL indexes and they would be fundamental sectors for economic development in Bengkulu.
\end{abstract}

Key words : sectoral linkage, key sektor, input-output analysis

\begin{abstract}
ABSTRAK
Penelitian ini bertujuan untuk mengevaluai keterkaitan ke belakang dan ke depan serta menentukan sektor utama yang mempunyai kontribusi dalam perekonomian Bengkulu. Analisa keterkaitan dan sektor utama menggunakan Tabel Input Output Propinsi Bengkulu tahun 2000. Hasil analisa menunjukkan bahwa struktur perekonomian propinsi masih didominasi oleh sektor pertanian dalam arti luas. Tiga sektor pertanian, yakni sektor kelapa sawit, sektor pertanian lainnya, serta peternakan dan produknya merupakan sektor utama dipropinsi Bengkulu yang diindikasi oleh tingginya indek keterkaitan ke belakang dan ke depan. Ke tiga sektor ini merupakan sektor fundamental dalam pembangunan ekonomi di propinsi ini.
\end{abstract}

Kata kunci: keterkaitan sektor, sektor utama, analisa input-output

\section{PENDAHULUAN}

Sektor ekonomi saling terkait dengan sektor lain melalui pembelian (purchase) dan penjualan (sales) baik secara langsung maupun tidak. Keterkaitan sektor melalui pembelian langsung ataupun tidak langsung dari sektor lain disebut dengan keterkaitan ke belakang (Backward Linkage). Sebaliknya, keterkaitan sektor melalui penjualan langsung maupun tidak langsung kepada sektor lain sering disebut dengan keterkaitan ke depan (Forward Linkage). Cai and Leung
(2002) mengatakan bahwa backward (BL) dan forward linkage (FL) suatu sektor adalah dua perspektif yang berbeda dalam melihat keterkaitannya dengan sektor yang lain. Kedua jenis keterkaitan ini melacak hubungan ke belakang dan depan sektor ekonomi suatu wilayah dimana keduanya hanya mengukur potensi efek suatu sektor. Pada sisi analisa keterkaitan ke belakang, asumsi yang digunakan dalam pengukuran ini adalah tidak adanya kendala input untuk semua sektor yang dianalisa, artinya semua sektor mempunyai input tenaga kerja, modal dan lahan 
untuk melakukan ekspansi. Sebaliknya, pada keterkaitan ke depan, asumsinya adalah sektor lain yang tergantung inputnya pada sektor yang dianalisa dan tidak adanya input substitusi.

Terkait dengan BL dan FL adalah analisa sektor utama suatu perekonomian. Rasmussen (1956) mengenalkan keberadaan kedua analisa keterkaitan dengan analisa sektor utama suatu perekonomian. Analisa sektor utama dalam suatu perekonomian memberikan bukti empirik struktur ekonomi suatu sektor dalam perekonomian suatu wilayah (Chenery and Watanabe 1958; Hewings and Romanos 1981; Hewings 1982; Defourny and Thorbecke 1984; Biaas and Gurgul 1998). Tujuan utama dari analisa ini adalah untuk menentukan sektor mana yang struktur ekonominya memberikan dampak yang paling besar dalam suatu perekonomian. Penelitian ini bertujuan untuk mengevaluasi keterkaitan ke belakang dan ke depan serta menentukan sektor utama dalam perekonomian propinsi Bengkulu. Pada bagian selanjutnya akan diuraikan secara singkat metode analisa dan data yang digunakan dalam penelitian ini. Bagian ini akan diikuti dengan diskusi hasil estimasi serta kesimpulan dan rekomendasi kebijakan akan dibahas pada bagian akhir penelitian ini.

\section{METODE PENELITIAN}

\section{Data dan sumber data}

Data yang digunakan dalam penelitian ini adalah Tabel Input Output Propinsi Bengkulu tahun 2000 yang dipublikasikan oleh Biro Pusat Statistik. Tabel IO ini terdiri atas 45 komoditi atau sektor (Tabel 1).

Tabel 1 Klasifikasi sektor dalam tabel IO Propinsi Bengkulu 2000

\begin{tabular}{llll}
\hline \hline No & Industri/Komoditi & No & Industri/Komoditi \\
\hline 1 & Padi & 26 & Ind. barang kayu, hasil hutan lainnya \\
2 & Jagung & 27 & Ind. kertas dan barang cetakan \\
3 & Tanaman umbi-umbian & 28 & Ind. pupuk, kimia dan barang dari karet \\
4 & Kacang-kacangan & 29 & Ind. semen dan barang galian bukan logam \\
5 & Sayur-sayuran dan buah-buahan & 30 & Ind. Alat angkutan, mesin dan peralatannya \\
6 & Padi-padian dan tabama lainnya & 31 & Ind. Barang lainnya \\
7 & Karet & 32 & Listrik, gas dan air bersih \\
8 & Kelapa & 33 & Bangunan \\
9 & Kelapa sawit & 34 & Perdagangan \\
10 & Kopi & 35 & Hotel dan Restoran \\
11 & Te h & 36 & Angkutan darat \\
12 & Cengkeh & 37 & Angkutan laut, sungai dan danau \\
13 & Kakao & 38 & Angkutan udara \\
14 & Hasil pertanian lainnya & 39 & Jasa penunjang angkutan \\
15 & Ternak dan hasil-hasilnya & 40 & Komunikasi \\
16 & Unggas, hewan lainnya dan hasil-hasilnya & 41 & Bank dan lembaga keuangan lainnya \\
17 & Kayu & 42 & Pemerintahan \\
18 & Hasil hutan dan perburuan lainnya & 43 & Jasa pendidikan dan kesehatan \\
19 & Perikanan laut dan hasil laut lainnya & 44 & Jasa lainnya \\
20 & Perikanan darat dan hasil perikanan darat & 45 & Kegiatan yang tak jelas batasannya \\
21 & Pertambangan batu bara dan mineral logam & & \\
22 & Pertambangan dan penggalian lainnya & & \\
23 & Industri penggilingan dan penyosohan padi dan kopi & \\
24 & Industri Makanan lainnya & & \\
25 & Industri tekstil, barrg kulit dan alas kaki & & \\
\hline
\end{tabular}


Metode Analisa

Model Input Output (IO) statis dapat diformulasikan sebagai berikut:

$y=(1-A) x$

dimana A merupakan matrik IO, $\mathrm{x}$ vektor output, dan y adalah vektor permintaan akhir (final demand). Dengan demikian, vektor $\mathrm{x}$ dapat diselesaikan sebagai berikut:

$$
x=(1-A)^{-1} y=B y
$$

Selanjutnya dengan mendefinisikan

$$
B_{i \bullet}=\sum_{j=1}^{n} b_{i j}, \quad B_{\bullet j}=\sum_{i=1}^{n} b_{i j} \text { dan } \quad V=\sum_{i, j=1}^{n} b_{i j},
$$

Sonis and Hewing (1989) memberikan formula matrik multiplier IO (dikenal dengan $M P M=$ Multiplier Product Matrix) sebagai berikut:

$$
\left.M=\frac{1}{V}\left[B_{i \bullet} B_{\bullet j}\right]=\frac{1}{V}\left[\begin{array}{c}
B_{1 \bullet} \\
B_{2 \bullet} \\
\mathrm{M} \\
B_{n \bullet}
\end{array}\right] \begin{array}{llll}
B_{\bullet 1} & B_{\bullet 2} & \Lambda & B_{\bullet n}
\end{array}\right]=\left[m_{i j}\right]
$$

Dengan demikian, struktur dari MPM sangat penting dikaitkan dengan ciri atau kondisi backward dan forward linkage suatu sektor seperti dijelaskan sebagai berikut:

Dengan mengasumsikan bahwa $B_{\bullet_{j 0}}$ adalah multiplier kolom terbesar dan $B_{i 0}$. sebagai multiplier baris terbesar, maka elemen yang terletak pada $(i 0, j 0)$ adalah sebagai berikut:

$m_{i 0, j 0}=\frac{1}{V} B_{i 0} \cdot B_{j 0} \bullet$

dimana elemen ini sering disebut sebagai nilai silang tertinggi (terbesar). Jika nilai ini dikeluarkan dari M, maka nilai terbesar ke dua akan diperoleh. Setelah dikeluarkannya baris $i 0$ dan $j 0$, maka nilai terbesar kedua $m_{i 0 j 0}$ akan dapat diperoleh dan seterusnya. Jumlah nilai silang sama dengan ranking dari matrik MPM. Dengan mengikuti rumusan yang dikemukakan oleh Rasmussen (1956), maka akan didapatkan indeks dari kebalikan Leontief (Leontief inverse), yang dikenal dengan keterkaitan ke belakang (Backward

Linkages) yang formulasinya sebagai berikut:

$$
B L_{j}=\frac{\frac{1}{n} \sum_{i=1}^{n} B_{i j}}{\frac{1}{n^{2}} \sum_{i, j=1}^{n} B_{i j}}=\frac{n B_{\bullet}}{V}
$$

dan keterkaitan ke depan (Forward Linkages) sebagai berikut:

$$
F L_{i}=\frac{\frac{1}{n} \sum_{i=1}^{n} B_{i j}}{\frac{1}{n^{2}} \sum_{i, j=1}^{n} B_{i j}}=\frac{n B_{i \bullet}}{V}
$$

Indek keterkaitan kebelakang yang lebih besar dari $1\left(B L_{j}>1\right)$ berarti unit perubahan dalam permintaan akhir dari sektor $j$ akan menciptakan di atas kenaikan rata-rata aktifitas dalam suatu perekonomian. Analoginya untuk keterkaitan ke depan adalah jika indek keterkaitan ke depan lebih besar dari satu $\left(F L_{i}>1\right)$, maka perubahan dalam semua sektor di permintaan akhir akan menciptakan kenaikan sektor i di atas rata-rata. Berangkat dari rumusan di atas, maka

1. Sektor $j$ dikatakan sebagai sektor utama apabila: $B L_{j}>1$ dan $F L_{i}>1$,

2. Sektor $j$ dikatakan mempunyai orientasi keterkaitan ke depan yang kuat jika tetapi ,

3. Sektor j mempunyai orientasi keterkaitan ke belakang yang kuat jika tetapi , dan

4. Sektor j mempunyai orientasi yang lemah jika dan .

Selanjutnya, piranti lunak (Software) GRIMP Versi 7.2 akan digunakan untuk menganalisa keterkaitan ke belakang dan ke depan terhadap sektor-sektor ekonomi di Propinsi Bengkulu.

\section{HASIL DAN PEMBAHASAN}

\section{Struktur ekonomi propinsi Bengkulu}

Kontribusi terbesar terhadap output yang dihasilkan dalam perekonomian berturut-turut adalah sektor tambang dan bahan galian, industri barang dan kayu, bangunan, serta batu bara dan logam, serta pemerintah seperti yang terlihat pada Gambar 1. Temuan ini berbeda dengan temuan di Propinsi Sulawesi Tenggara seperti yang dilaporkan oleh Ilyas (2001). Ilyas menunjukkan bahwa komposisi sektor-sektor ekonomi yang 
memberikan kontribusi terbesar dalam perekonomian pada Propinsi Sulawesi Tenggara, antara lain seperti bangunan/konstruksi, sektor pengolahan serta sektor pemerintahan dan pertahanan. Struktur perekonomian Propinsi Bengkulu didominasi oleh usaha primer seperti sektor pertambangan dan bahan galian (sektor 22) serta batubara dan logam (sektor 21). Sektor ini mempunyai kontribusi kurang lebih $17.5 \%$ dari total output yang dihasilkan propinsi ini. Sektor ini kemudian diikuti oleh sektor industri barang kayu yang mempunyai kontribusi sebesar $8.42 \%$. Di samping sektor pertanian tanaman pangan (padi, jagung) dan perkebunan (kopi, teh, karet, dan kelapa sawit) serta hasil-hasil hutan kayu dan nonkayu. Di antara sektor pertanian, subsektor kelapa sawit (sektor 9), padi (sektor 1) dan kacangkacangan (sektor 4) mempunyai peranan yang cukup signifikan dengan kontribusi lebih dari 3 persen terhadap perekonomian Bengkulu.

Kontribusi yang dominan sektor tambang dan bahan galian, industri barang dan kayu, bangunan, serta batu bara dan logam, serta pemerintah dalam perekonomian akan mendorong kemandirian suatu sektor dalam perekonomian dalam menyangga struktur ekonomi secara keseluuruhan. Dimana sektor yang menjadi penyangga struktur ekonomi ini diharapkan akan menjadi penggerak pertumbuhan sektor lainnya. Namun kemampuan suatu sektor dalam menopang perekonomian Propinsi Bengkulu tidak hanya dinilai dari indikasi kontribusinya tetapi juga indikasi keterkaitan ke belakang dan ke depan antar sektor dalam perekonomian Propinsi Bengkulu.

Dilihat dari sisi pengeluaran tampak bahwa perkonomian Bengkulu pada tahun 2000 masih didominasi oleh pengeluaran konsumsi baik yang dilakukan oleh rumahtangga maupun pemerintah (Tabel 2). Ke dua sektor ini kontribusinya terhadap gross domestik produk mencapai lebih dari $77 \%$. Sedangkan untuk investasi hanya sebesar $8 \%$. Ini berarti gerak pertumbuhan perekonomian propinsi Bengkulu utamanya digerakan oleh konsumsi daripada investasi atau surplus perdagangan (eksport minus import). Kontribusi surplus perdagangan propinsi Bengkulu kurang dari $1 \%$.

Tabel 2 Penggunaan PDB berdasarkan tabel I-O 2000

\begin{tabular}{|c|c|c|c|}
\hline \multirow{2}{*}{\multicolumn{2}{|c|}{ Komponen }} & \multicolumn{2}{|c|}{2000} \\
\hline & & $\begin{array}{l}\text { Nilai } \\
\text { (Rp } 000 \text { 000) }\end{array}$ & Share $(\%)$ \\
\hline$\overline{1 . \mathrm{K}}$ & isumsi rumah tangga & 3065319 & 62.97 \\
\hline $2 \mathrm{~K}$ & isumsi pemerintah & 770101 & 15.82 \\
\hline $3 \mathrm{P}$ & abentukan modal tetap & 402774 & 8.27 \\
\hline $4 \mathrm{P}$ & ubahan stok & -126397 & -2.60 \\
\hline $5 \mathrm{E}$ & por barang dan jasa neto & 756301 & 15.54 \\
\hline & & 486809 & 100.00 \\
\hline
\end{tabular}

Sumber: Tabel I-O Provinsi Bengkulu 2000

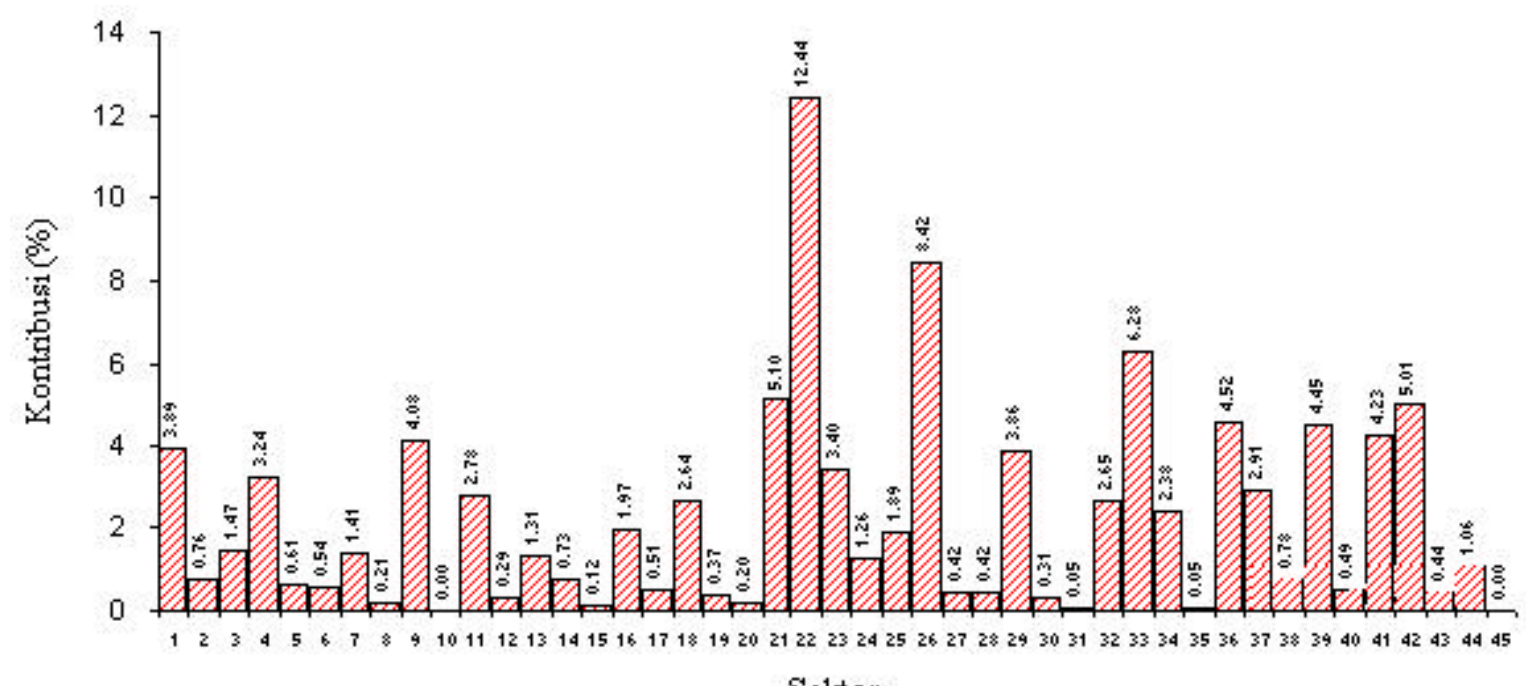

Sektor

Gambar 1. Kontribusi sektor terhadap total output 
Analisa keterkaitan sektor

Ploting sektor berdasarkan indek keterkaitan ke belakang dan ke depan masing-masing sektor (Gambar 2). Hasil ploting menunjukkan bahwa ada 4 (empat) kuadran yang menunjukkan kuat dan lemahnya indek keterkaitan sektor. Kuadran sektor utama, misalnya, adalah sektor-sektor yang mempunyai indek keterkaitan ke belakang dan ke depan lebih dari satu. Apabila sektor memiliki indek keterkaitan kebelakang lebih dari satu dan indek keterkaitan ke depan kurang dari satu, maka sektor ini akan masuk pada kuadran sektor dengan orientasi keterkaitan ke belakang yang kuat. Sebaliknya, jika sektor mempunyai indek keterkaitan ke depan yang lebih dari satu dan indek keterkaitan ke belakang kurang dari satu maka sektor ini akan dimasukkan pada sektor dengan orientasi keterkaitan ke depan yang kuat. Sedangkan sektor dengan indek keterkaitan ke belakang dan ke depan kurang dari satu, maka sektor ini dikalisifikasikan pada kuadran sektor dengan orientasi keterkaitan yang lemah. Angka indek ini diperoleh dengan mengukur nilai atau ukuran keterkaitan sektor dengan rata-rata keterkaitan semua sektor (Cai and Leung 2002).
Hasil analisa keterkaitan sektor dapat disimpul kan bahwa 39\% sektor di Propinsi Bengkulu merupakan sektor-sektor yang mempunyai orientasi keterkaitan ke belakang $\left(B L_{j}>1\right)$ (Gambar 2). Ini berarti bahwa sektor-sektor yang ada lebih banyak menggunakan input dari sektor lain dibandingkan dengan menghasilkan suatu output untuk dijual kepada sektor lain sebagai input. Di antara sektor yang mempunyai orientasi keterkaitan kebelakang yang kuat adalah sektor Pertambangan batu bara dan mineral logam (sektor 21), Industri penggilingan dan penyosohan padi dan kopi (sektor 23) serta Industri tekstil, barang kulit dan alas kaki (sektor 25).

Gambar 2 juga menunjukkan bahwa hanya ada 9 sektor atau $20.5 \%$ yang mempunyai orientasi keterkaitan ke depan lebih dari satu $\left(F L_{i}>1\right)$. Kuatnya indeks $F L_{i}$ menginformasikan bahwa sektor ini mempunyai kemampuan untuk memproduksi output yang dapat dimanfaatkan oleh sektor lain sebagai input. Diantara sektor yang termasuk dalam kelompok ini adalah sektor padi, karet, teh, ternak dan hasilnya, perikanan laut serta Industri pupuk, kimia dan barang dari karet.

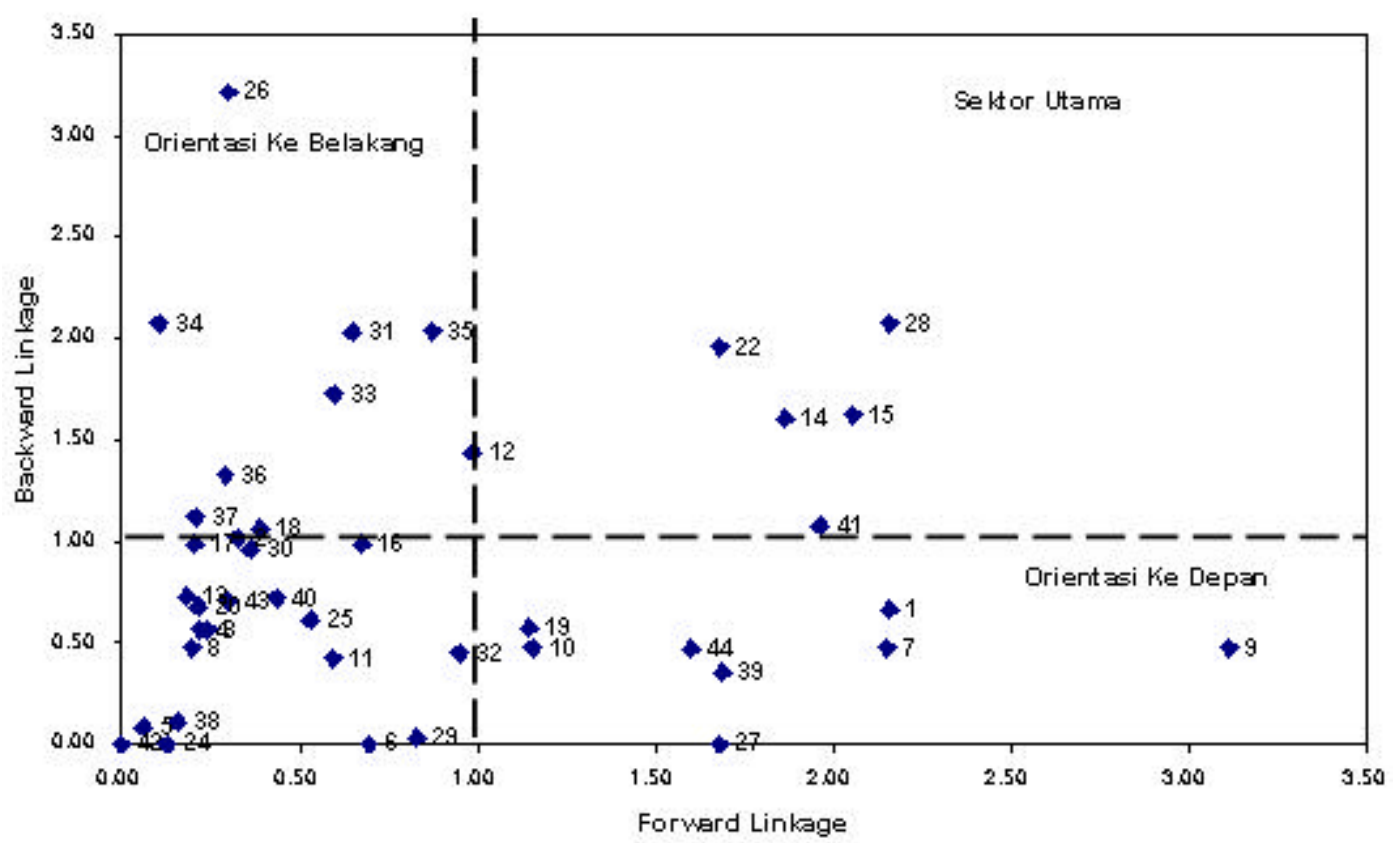

Gambar 2. Kaitan ke belakang dan ke depan masing-masing sektor ekonomi Propinsi Bengkulu tahun 2000 
Tabel 3. Dampak output total: I-O Bengkulu

\begin{tabular}{|c|c|c|c|c|c|c|c|c|}
\hline Sektor & $\begin{array}{c}\text { Dampak } \\
\text { Awal } \\
\end{array}$ & $\begin{array}{l}\text { Pengaruh } \\
\text { Langsung }\end{array}$ & $\begin{array}{c}\text { Pengaruh } \\
\text { Tidak Langsung }\end{array}$ & $\begin{array}{l}\text { Dampak } \\
\text { Imbasan }\end{array}$ & $\begin{array}{c}\text { Dampak } \\
\text { Total } \\
\end{array}$ & Luberan & Tipe I & Tipe II \\
\hline Padi & 1.000 & 0.154 & 0.030 & 0.350 & 1.534 & 0.000 & 1.184 & 1.534 \\
\hline Jagung & 1.000 & 0.235 & 0.077 & 0.277 & 1.589 & 0.005 & 1.312 & 1.589 \\
\hline Umbi2an & 1.000 & 0.131 & 0.025 & 0.213 & 1.370 & 0.363 & 1.157 & 1.370 \\
\hline Kacang2an & 1.000 & 0.131 & 0.031 & 0.248 & 1.410 & 0.000 & 1.162 & 1.410 \\
\hline Sayur\&buah & 1.000 & 0.019 & 0.006 & 0.273 & 1.298 & 0.000 & 1.025 & 1.298 \\
\hline Tabamalain & 1.000 & 0.000 & 0.000 & 0.000 & 1.000 & 0.004 & 1.000 & 1.000 \\
\hline Karet & 1.000 & 0.110 & 0.020 & 0.888 & 2.018 & 0.000 & 1.130 & 2.018 \\
\hline Kelapa & 1.000 & 0.110 & 0.023 & 0.295 & 1.429 & 0.000 & 1.134 & 1.429 \\
\hline Klp Sawit & 1.000 & 0.110 & 0.018 & 0.402 & 1.531 & 0.727 & 1.128 & 1.531 \\
\hline Kopi & 1.000 & 0.110 & 0.014 & 0.475 & 1.599 & 0.005 & 1.124 & 1.599 \\
\hline Teh & 1.000 & 0.097 & 0.013 & 0.409 & 1.519 & 0.001 & 1.110 & 1.519 \\
\hline Cengkeh & 1.000 & 0.333 & 0.152 & 0.419 & 1904 & 0.148 & 1.485 & 1904 \\
\hline Kakao & 1.000 & 0.169 & 0.094 & 0.255 & 1.518 & 0.002 & 1.262 & 1.518 \\
\hline Pert lain & 1.000 & 0.373 & 0.133 & 0.262 & 1.768 & 0.008 & 1506 & 1.768 \\
\hline Ternak\&hsl & 1.000 & 0.377 & 0.149 & 0.339 & 1.865 & 0.006 & 1527 & 1.865 \\
\hline Unggas\&hs1 & 1.000 & 0.230 & 0.068 & 0.277 & 1.575 & 0.002 & 1.298 & 1.575 \\
\hline Kayu & 1.000 & 0.230 & 0.174 & 0.305 & 1.709 & 0.000 & 1.404 & 1.709 \\
\hline HsIHutan & 1.000 & 0.367 & 0.164 & 0.541 & 2.072 & 1.697 & 1.531 & 2.072 \\
\hline PrikanLaut & 1.000 & 0.134 & 0.063 & 0.603 & 1.799 & 0.003 & 1.196 & 1.799 \\
\hline PrikanDart & 1.000 & 0.157 & 0.030 & 0.076 & 1.264 & 0.030 & 1.188 & 1.264 \\
\hline Btbara\&1gm & 1.000 & 0.830 & 0.206 & 0.324 & 2.360 & 0.072 & 2.036 & 2.360 \\
\hline Tbang\&gali & 1.000 & 0.222 & 0.039 & 0.405 & 1.666 & 0.079 & 1.261 & 1.666 \\
\hline $\begin{array}{l}\text { Indgiling } \\
\text { Indmakanan }\end{array}$ & $\begin{array}{l}1.000 \\
1.000\end{array}$ & $\begin{array}{l}0.821 \\
0.000\end{array}$ & $\begin{array}{l}0.111 \\
0.000\end{array}$ & $\begin{array}{l}0.323 \\
0.000\end{array}$ & $\begin{array}{l}2.255 \\
1.000\end{array}$ & $\begin{array}{l}0.011 \\
0.000\end{array}$ & $\begin{array}{l}1.932 \\
1.000\end{array}$ & $\begin{array}{l}2.255 \\
1.000\end{array}$ \\
\hline Tekstilkul & 1.000 & 0.839 & 0398 & 0.285 & 2522 & 1.612 & 2.237 & 2522 \\
\hline Indbrgkayu & 1.000 & 0.281 & 0.058 & 0.608 & 1.948 & 1.615 & 1.339 & 1.948 \\
\hline Krtas\&ceta & 1.000 & 0.000 & 0.000 & 0.000 & 1.000 & 0.096 & 1.000 & 1.000 \\
\hline PpkKimKare & 1.000 & 0.000 & 0.000 & 0.000 & 1.000 & 0.000 & 1.000 & 1.000 \\
\hline Smen\&N1og & 1.000 & 0.006 & 0.000 & 0.019 & 1.025 & 0.391 & 1.006 & 1.025 \\
\hline IndA1Angku & 1.000 & 0.456 & 0.077 & 0.441 & 1.974 & 0.000 & 1.534 & 1.974 \\
\hline BrgLainnya & 1.000 & 0.472 & 0.156 & 0.520 & 2.149 & 0.000 & 1.629 & 2.149 \\
\hline LstrGasAir & 1.000 & 0.568 & 0.143 & 0.486 & 2.197 & 1.226 & 1.711 & 2.197 \\
\hline Bangunan & 1.000 & 0.063 & 0.029 & 0.290 & 1.383 & 0.138 & 1.093 & 1.383 \\
\hline Pdagangan & 1.000 & 0.483 & 0.168 & 0.255 & 1.905 & 0.000 & 1.651 & 1.905 \\
\hline Hotel\&Rest & 1.000 & 0.242 & 0.121 & 0.228 & 1.590 & 0.000 & 1.363 & 1.590 \\
\hline AngkDarat & 1.000 & 0.308 & 0.079 & 0.352 & 1.739 & 0.023 & 1.387 & 1.739 \\
\hline AngkLaut & 1.000 & 0.262 & 0.078 & 0.539 & 1.879 & 0.008 & 1.340 & 1.879 \\
\hline AngkUdara & 1.000 & 0.026 & 0.003 & 0.047 & 1.076 & 0.000 & 1.029 & 1.076 \\
\hline PenunjAngk & 1.000 & 0.313 & 0.153 & 0.418 & 1.884 & 0.095 & 1.466 & 1.884 \\
\hline Komunikasi & 1.000 & 0.167 & 0.071 & 0.155 & 1.393 & 0.000 & 1.238 & 1.393 \\
\hline BankKuanga & 1.000 & 0.251 & 0.080 & 0.155 & 1.486 & 0.000 & 1.331 & 1.486 \\
\hline Pemerintah & 1.000 & 0.000 & 0.000 & 1571 & 2571 & 2509 & 1.000 & 2571 \\
\hline PenddkKesh & 1.000 & 0.165 & 0.054 & 0.707 & 1.925 & 1.048 & 1.218 & 1.925 \\
\hline JasaLainya & 1.000 & 0.108 & 0.023 & 0.193 & 1.325 & 0.045 & 1.132 & 1.325 \\
\hline KegLainnya & 1.000 & 0.000 & 0.000 & 0.000 & 1.000 & 0.234 & 1.000 & 1.000 \\
\hline
\end{tabular}


Lebih lanjut, lebih dari 40 persen sektor mempunyai kecenderungan orientasi keterkaitan ke belakang ataupun ke depan yang lemah dimana indeks $B L_{j}<1$ dan $F L_{i}<1$. Yang termasuk ke dalam kelompok ini antara lain sektor umbiumbian, sayur dan buah-buahan, kacangkacangan, kakao serta unggas dan hasil olahannya. Salah satu alasan yang dapat menerangkan temuan ini adalah sektor-sektor ini menggunakan input yang harus diimport dari luar propinsi Bengkulu, seperti pupuk dan pestisida, dan output yang dihasilkan lebih banyak dijual untul konsumsi terakhir atau langsung dieksport ke luar Bengkulu.

Berbeda dengan hasil penelitian Dermorejo (2001) menginformasikan bahwa sektor-sektor seperti agroindustri memiliki kaitan ke belakang terbesar sedangkan sektor pertambangan dan penggalian memiliki kaitan ke belakang terkecil dalam perekonomian Propinsi Jawa Barat. Sementara sektor jasa dan industri non-migas (termasuk minyak) memiliki kaitan ke depan terbesar

\section{Analisa sektor utama}

Sektor-sektor seperti pertanian seperti cengkeh (sektor 12), pertanian lain (sektor 14), serta sektor ternak dan hasilnya (sektor 15) memiliki kaitan ke belakang dan ke depan yang kuat (Gambar 2). Sektor-sektor ini secara signifikan menggunakan output sektor lain sebagai input. Output sektor ini juga digunakan sebagai input oleh sektor lainnya, sehingga sektor-sektor ini menjadi sektor utama dalam perekonomian Propinsi Bengkulu.

Hasil analisa koefisien multiplier menunjukkan bahwa sektor cengkeh (sektor 12), pertanian lain (sektor 14), serta sektor ternak dan hasilnya (sektor 15) berturut-turut memiliki pengganda output 1.904; 1.768 dan 1.865. Meskipun sebagai sektor utama dalam perekonomian Propinsi Bengkulu namun dampak total yang merupakan penjumlahan dampak awal, pengaruh langsung, pengaruh tidak langsung dan dampak imbasan konsumsi sektor ini terhadap sektor lainnya relatif sangat kecil (Tabel 3). Hal ini diindikasikan oleh nilai dampak output yang kecil dibandingkan sektor lainnya seperti tekstil dan kulit, pemerintah, batubara dan logam, industri giling, serta karet. Artinya injeksi permintaan akhir sebesar Rp.1 juta terhadap output yang dihasilkan oleh sektor utama lebih kecil dibandingkan injeksi permintaan terhadap output yang dihasilkan sektor non-utama.

Dampak bersih sektor utama (selisih antara dampak total dan dampak awal), menurut Muchdie (2002) mencerminkan dampak suatu sektor dalam perekonomian yang sesungguhnya. Berdasarkan asumsi tersebut sektor utama dalam perekonomian Prpinsi Bengkulu memiliki nilai lebih rendah dibandingkan misalnya terhadap sektor tekstil dan kulit, dan pemerintah. Artinya meningkatnya permintaan terhadap output sektor utama sebesar Rp.1.000 hanya menghasilkan dampak bersih output perekonomian secara keseluruhan sebesar Rp.148,- dan Rp.6,-

Secara keseluruhan sektor pertanian di Propinsi Bengkulu masih menjadi penopang utama perekonomian di Propinsi Bengkulu. Pengembangan sektor pertanian berpotensi memberikan efek yang besar dalam perekonomian. Penelitian Cai and Pingsun (2002) juga menunjukkan bahwa sektor-sektor pertanian seperti perkebunan tebu, peternakan, perkebunan kopi, dan perikanan, di Hawaii memiliki kaitan ke belakang dan ke depan yang kuat sehingga menjadi sektor-sektor utama dalam pengembangan ekonomi di wilayah tersebut.

\section{KESIMPULAN}

Sektor-sektor seperti pertanian seperti cengkeh, pertanian lain, serta sektor ternak dan hasilnya memiliki kaitan ke belakang dan ke depan yang kuat. Sektor-sektor ini secara signifikan menggunakan output sektor lain sebagai input. Output sektor ini juga digunakan sebagai input oleh sektor lainnya, sehingga sektor-sektor ini menjadi sektor utama dalam perekonomian Propinsi Bengkulu. Meskipun sebagai sektor utama dalam perekonomian Propinsi Bengkulu namun dampak total sektor ini terhadap sektor lainnya sangat kecil, yang diindikasikan oleh nilai dampak output yang kecil dibandingkan sektor lainnya seperti tekstil dan kulit, pemerintah, batubara dan logam, industri giling, serta karet. 
Secara keseluruhan sektor pertanian di Propinsi Bengkulu masih menjadi penopang utama perekonomian di Propinsi Bengkulu, sehingga pengembangan sektor pertanian secara keseluruhan berpotensi memberikan efek yang besar dalam perekonomian.

\section{UCAPAN TERIMAKASIH}

Penelitian ini merupakan bagian dari Penelitian Hibah 2006 yang didanai oleh DP2M, DIKTI. Untuk itu, peneliti mengucapkan terima kasih atas didanainya penelitian ini. Ucapan terimakasih juga disampaikan kepada semua pihak yang telah memberikan masukan pada penulisan artikel ini.

\section{DAFTAR PUSTAKA}

Biaas, S., and H. Gurgul. 1998. Hypothesis about the second eigenvalue of the Leontief matrix. Economic Systems Research. 10 : 285-9.

Cai, J. and P. Leung. 2002. The linkage of agriculture to Hawaii's economy. Economic Issues. University if Hawaii at Manoa. El$4: 1-8$.

Chenery, H. B., and T. Watanabe. 1958. International comparisons of the structure of production. Econometrica. 26 (4): 487-521.

Defourny, J., and E. Thorbecke. 1984. Structural path analysis and multiplier decomposition within a social accounting framework. Economic Journal. 94:111-36.

Dermorejo, S.K. 2001. Penentuan prioritas sektor untuk menyumbang kebijkasanaan fiskal dalam era otonomi daerah di Propinsi Jawa Barat. Seminar Progam Pasca Sarjana IPB, Bogor.

Hewings, G. J. D. 1982. The empirical identification of key-sektors in an economy: A regional perspective. The Developing Economies. 20:173-95.

Hewings, G. J. D., and M. C. Romanos. 1981. Simulating less developed regional economies under conditions of limited information. Geographical Analysis. 13 (4): 373-90.

Ilyas, M. 2001. Analisis kesiapan potensi ekonomi wilayah di Sulawesi Tenggara terhadap kemandirian pembangunan dalam pelaksanaan otonomi daerah. Seminar Program Pasca Sarjana IPB, Bogor.

Muchdie. 2002. Aplikasi model input-output dalam analisis perekonomian wilayah. Pengembangan Wilayah dan Otonomi Daerah (kajian Konsep dan Pengembangan) BPPT, Jakarta.

Rassmusen, P. 1956. Studies in Inter-Sektoral Relations. Einar Harks, Copenhagen

Sonis, M., and G. J. D. Hewings. 1989. Errors and sensitivity in input-output analysis: new approach. In Frontiers in input-output analysis, eds. R. Miller, K. Polenske, and A. Rose. Oxford University Press, New York 